\title{
Interaction of thermal waters with carbonate and aluminosilicate minerals: a case study of Bang mineral hot spring, Central Vietnam
}

\author{
Dmitry A. Novikov ${ }^{1,2, *}$, Phan Thi Kim $\mathrm{Van}^{3}$, Doan Van Tuyen ${ }^{3}$, Do Thi Thu ${ }^{3}$, Fedor F. \\ Dultsev ${ }^{1}$, Anatoliy V. Chernykh ${ }^{1}$, and Tran Viet Hoan ${ }^{4}$ \\ ${ }^{1}$ Trofimuk Institute of Petroleum Geology and Geophysics SB RAS, Laboratory of Hydrogeology of \\ Sedimentary Basins of Siberia, 630090 Koptyug ave. 3, Novosibirsk, Russia \\ ${ }^{2}$ Novosibirsk State University, Geological and Geophysical Department, 630090 Pirogov str. 1, \\ Novosibirsk, Russia \\ ${ }^{3}$ Institute of Geological Sciences, Vietnam Academy of Science and Technology (VAST), 84 Chua \\ Lang, Dong Da, Hanoi, Vietnam \\ ${ }^{4}$ National Centre for Water Resources Planning and Investigation, 93/95 Vu Xuan Thieu Street, Sai \\ Dong Ward, Long Bien District, Hanoi, Vietnam
}

\begin{abstract}
Results of the studies of water-rock interactions for the Bang thermal water system (Bang Mineral Hot Spring) in Kuang Binh province, Central Vietnam, are presented for the first time. It was established that the thermal waters $\left(62.1-97.1^{\circ} \mathrm{C}\right)$ with total mineralization of $255-659 \mathrm{mg} / \mathrm{dm}^{3}$ of $\mathrm{HCO}_{3}-\mathrm{Na}$ composition are supersaturated with respect to carbonate minerals (calcite, magnesite, and dolomite) and saturated with respect to albite, microcline, laumontite, and glaucophane. The waters with the outlet temperature of $24.3-34.5{ }^{\circ} \mathrm{C}$, with mineralization $44-87 \mathrm{mg} / \mathrm{dm}^{3}$ and composition $\mathrm{HCO}_{3}-\mathrm{Cl}-\mathrm{Na}-\mathrm{Mg}$ are unsaturated with respect to carbonates and are in the fields of stability of clay minerals: kaolinite, illite, Na-, Ca-, and $\mathrm{Mg}$-montmorillonite. Theseresults are in good agreement with the results of the isotope composition analysis of the hydrothermal vents $(\delta \mathrm{D}$, $\delta^{18} \mathrm{O}$ and ${ }^{3} \mathrm{H}$ ), according to which the time of water circulation for the first-group is higher than 60 years and may reach more than 1000 years, while for the second-group water it does not exceed 50 years.
\end{abstract}

\section{Introduction}

Thermal waters of Vietnam have been investigated for several decades. Numerous studies describingtheir baseline hydrogeological conditions, along with the main geological and structural features and tectonic regime, and hydrogeochemistry were carried out for major geothermal areas [1-10]. However, many aspects related to the formation of the chemical and isotopic composition of thermal waters still remain unclear. It would not be possible to solve this problem without in-depth studies of the thermodynamic equilibrium of

* Corresponding author: NovikovDA@ipgg.sbras.ru 
hydrothermal vent fluids with principal minerals of the host rocks. In our previous studies $[1-2,4]$ we considered hydrogeochemistry and the isotopic composition of thermal waters in Central Vietnam and, specifically, hydrothermal vents of the Bang thermal water deposit [3]. Accordingly, this paper aims to address equilibrium speciation for the thermal waters - rock system.

The Bang thermal water deposit is confined to the zone of tectonic disturbance associated with the two intersecting large faults: Kyen Zhan fault (striking N-S and is traced by the eponymous river) and Bang fault (striking NW -SE). Hydrothermal vents and intense fumarolic activity are observed. The total discharge rate of highly thermal water $\left(75-97^{\circ} \mathrm{C}\right)$ is more than $40 \mathrm{~L} / \mathrm{s}$. Travertine formations (up to 1.0-1.5 $\mathrm{m}$ in diameter ) are deposited at the hydrothermal vents.

\section{Results and discussion}

Thermal waters with total mineralization varying between 44 and $659 \mathrm{mg} / \mathrm{dm}^{3}$ are widespread at the Bang deposit. Their composition is mainly sodium bicarbonate, sodium-magnesium bicarbonate-chloride (after S.A. Shchukarev [11]) (Fig. 1.a).

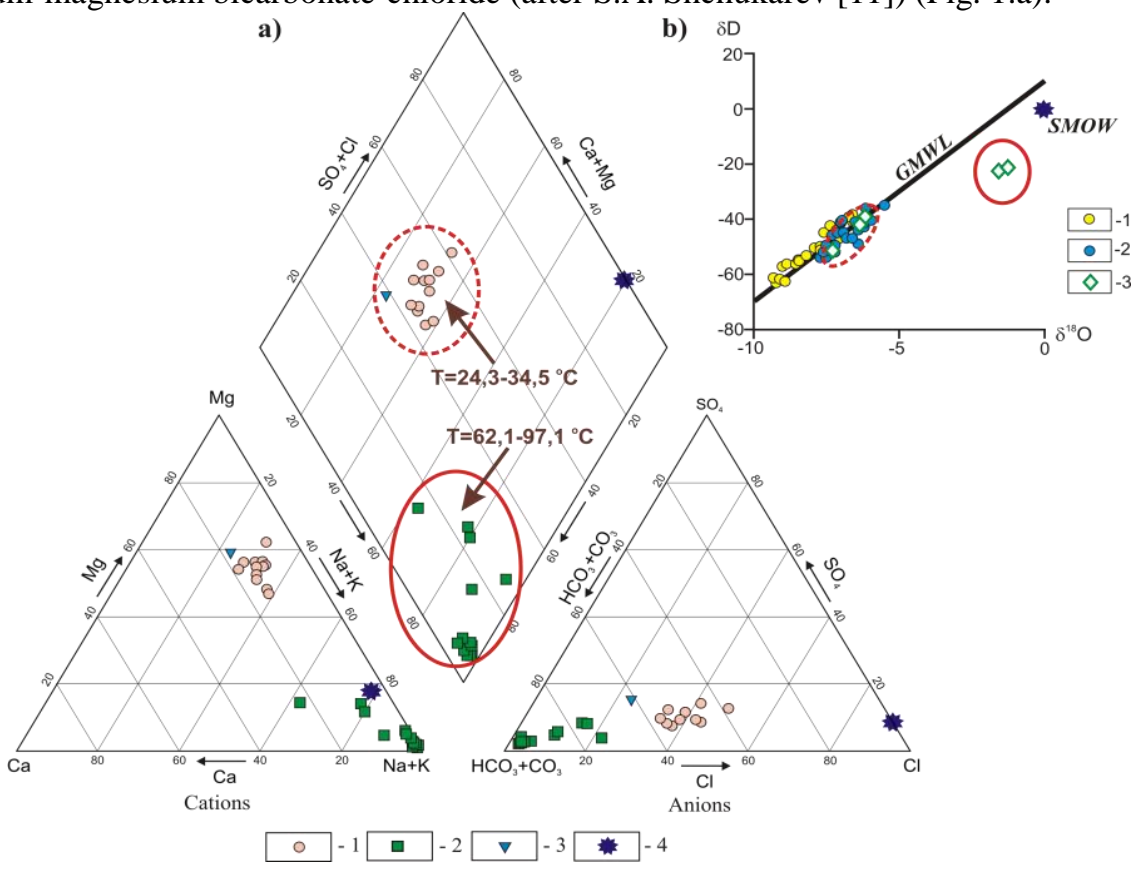

Fig. 1. Piper diagram (a) and the isotope composition (b) of thermal water in the Bang deposit a) Chemical types of water according to $\mathrm{S}$. A. Shchukarev: $1-\mathrm{Na}-\mathrm{Mg}-\mathrm{HCO}_{3}-\mathrm{Cl} ; 2-\mathrm{Na}-\mathrm{HCO}_{3} ; 3-$ $\mathrm{Mg}-\mathrm{Na}-\mathrm{HCO}_{3} ; 4$ - seawater;

b) Thermal water: 1 - continent, 2 - coastal regions, 3 - hydrothermal vents of the Bang deposit.

The studied waters differing from each other in the composition and in the amounts of major macro- and microcomponents depending on the temperature of hydrothermal fluids pouring out of a vent can be divided into two hydrogeochemical groups: 1) waters with temperature at the spring outlet of $24.3-34.5^{\circ} \mathrm{C}$ (sodium-magnesium hydrocarbonate-chloride composition; total mineralization $\left.44-87 \mathrm{mg} / \mathrm{dm}^{3} ; 2\right)$ waters with temperature from 62.1 to $97.1^{\circ} \mathrm{C}$ (sodium bicarbonate in composition; total mineralization $255-659 \mathrm{mg} / \mathrm{dm}^{3}$ ). The studied thermal waters are distinguished by salinity not more than $1 \mathrm{~g} / \mathrm{dm}^{3}$, which may be explained by their composition being formed within the limits of nonstratified sub-units of 
hydrogeological massifs within the region of the wide occurrence of intrusive rocks resistant to weathering processes. Water circulation proceeds along the water-bearing zones of exogenous fracturing and tectonic faults. Analysis of the distribution of points for the hydrothermal vent positions with different chemical compositions depending on $\delta^{18} \mathrm{O}$ and $\delta \mathrm{D}$ values provides the evidence that there are two possible genetic types of water. The aqueous component of one of them is based on meteoric water and to an insignificant extent on seawater (thalassogenic), while the group of soda waters with the maximal values of $\delta^{18} \mathrm{O}$ and $\delta \mathrm{D}$ related to fumaroles has a deeper source (Fig. 1.b) [3]. Besides, the data on tritium $\left({ }^{3} \mathrm{H}\right.$ ) concentrations point to different times of water circulation for these two groups. In the former case, circulation time does not exceed 50 years $\left({ }^{3} \mathrm{H}=4.3-11.1 \mathrm{TE}\right)$, while in the latter case the circulation time exceeds 60 years and may be much longer $\left({ }^{3} \mathrm{H}=0.5 \mathrm{TE}\right)$.

The interaction of thermal water with carbonate minerals (calcite, magnesite and dolomite) occurs through the reaction of congruent dissolution, while the mechanism of incongruent dissolution of aluminosilicate minerals is connected mainly with hydrolysis.

Investigations of the carbonate minerals - thermal waters equilibria are important not only in terms of obtaining information on the transformation of the water composition but for evaluation of the degree of water saturation with respect to aluminosilicate minerals because there always is a carbonate barrier in the way to such saturation. Analysis of the water saturation plots with respect to calcite, magnesite and dolomite showed that (Fig. 2.a-c): waters with temperature varying from 62.1 to $97.1^{\circ} \mathrm{C}$ (almost all of them are supersaturated with respect to calcite and magnesite, of which both may precipitate as secondary mineral phases, and to a lesser extent with respect to dolomite,); waters with temperature in the range of $24.3-34.5^{\circ} \mathrm{C}$ (which are unsaturated with respect to carbonate minerals).
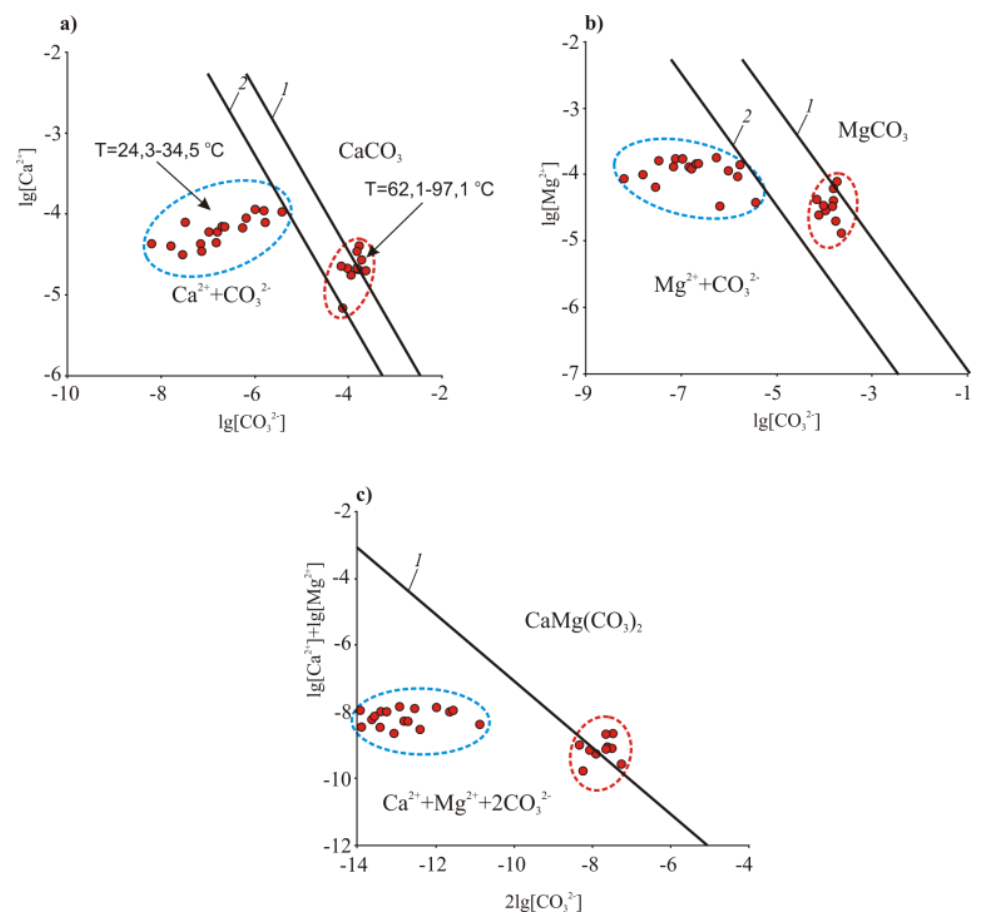

Fig. 2. The saturation degree plots for thermal water of the Bang deposit with calcite (a), magnesite (b), and dolomite (c) at $25^{\circ} \mathrm{C}$ (line 1) and $100^{\circ} \mathrm{C}$ (line 2).

Calculation of the equilibria of thermal waters with respect to the major aluminosilicate minerals has shown a more interesting pattern comprising four groups (I, II, III and IV) of the 
distinguished points. Groups I and IV correspond to those distinguished previously from the plots for carbonate minerals (Fig. 2), while groups II and III include hydrothermal spring outlets No. 8 and 9 (in the temperature range of 68.4-69.1 ${ }^{\circ} \mathrm{C}$ ) confined to Kyen Zhan fault, and wells No. 13 and 14, also located in the zone affected by this fault.

Analysis of the plotted data (Fig. 3) suggests that all the studied high-temperature waters (group I) are saturated with respect to albite, microcline, laumontite, glaucophane and unsaturated with respect to anorthite and forsterite; waters with temperature $24.3-34.5{ }^{\circ} \mathrm{C}$ occur within the stability fields of clay minerals: kaolinite, illite and $\mathrm{Na}-, \mathrm{Ca}-$, and Mg-montmorillonite.
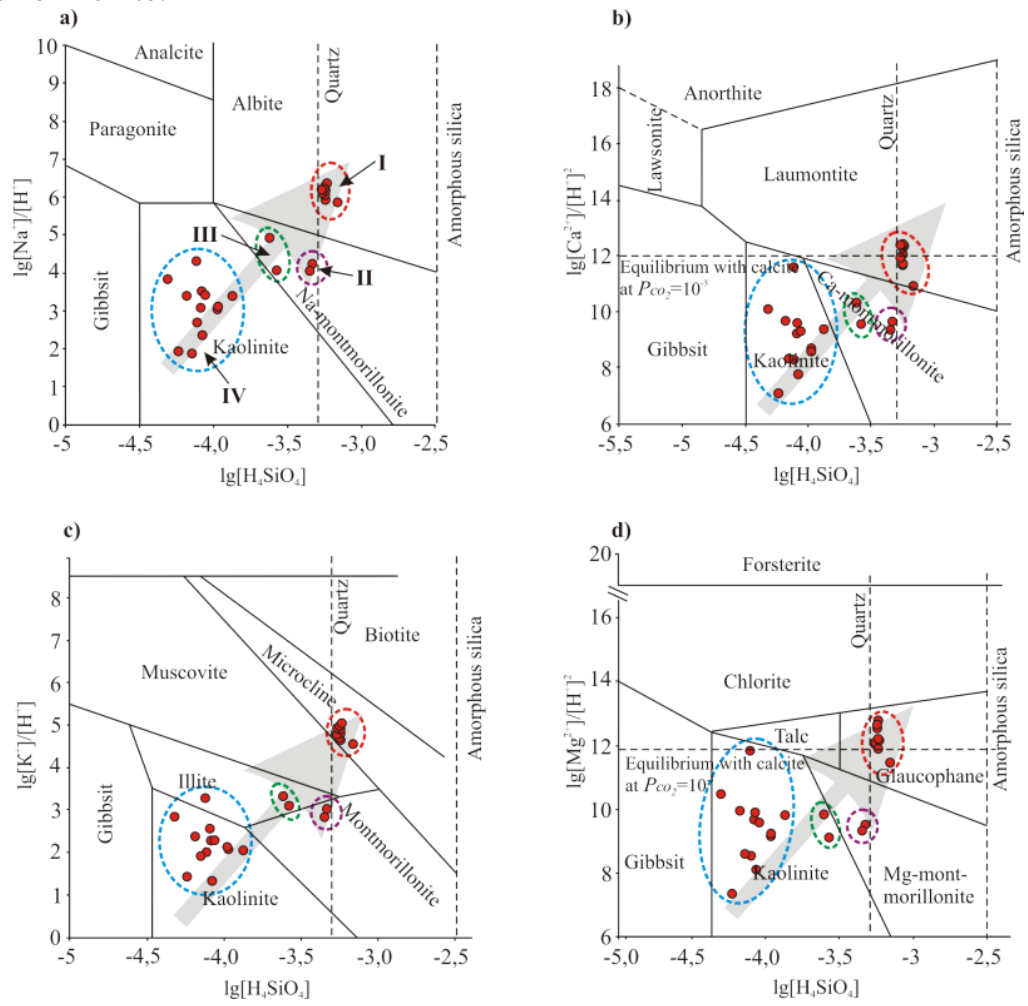

Fig. 3. The mineral stability plots for the systems: $\mathrm{HCl}-\mathrm{H}_{2} \mathrm{O}-\mathrm{Al}_{2} \mathrm{O}_{3}-\mathrm{Na}_{2} \mathrm{O}-\mathrm{SiO}_{2}$ (a),

$\mathrm{HCl}-\mathrm{H}_{2} \mathrm{O}-\mathrm{Al}_{2} \mathrm{O}_{3}-\mathrm{CaO}-\mathrm{SiO}_{2}$ (b), $\mathrm{SiO}_{2}-\mathrm{Al}_{2} \mathrm{O}_{3}-\mathrm{K}_{2} \mathrm{O}-\mathrm{CO}_{2}-\mathrm{H}_{2} \mathrm{O}$ (c), $\mathrm{HCl}-\mathrm{H}_{2} \mathrm{O}-\mathrm{Al}_{2} \mathrm{O}_{3}-\mathrm{MgO}-\mathrm{SiO}_{2}$ (d) at 100 ${ }^{\circ} \mathrm{C}$ showing also the data on the composition of thermal water from the Bang deposit

Thus, in the system $\mathrm{HCl}-\mathrm{H}_{2} \mathrm{O}-\mathrm{Al}_{2} \mathrm{O}_{3}-\mathrm{Na}_{2} \mathrm{O}-\mathrm{SiO}_{2}$ (Fig. 3.a) the points tend to be concentrated in the stability fields of albite, kaolinite and (to a lesser extent) Na-montmorillonite. In the system $\mathrm{HCl}-\mathrm{H}_{2} \mathrm{O}-\mathrm{Al}_{2} \mathrm{O}_{3}-\mathrm{CaO}-\mathrm{SiO}_{2}$ (Fig. 3.b), all the studied waters are located within the stability fields of kaolinite, Ca-montmorillonite and laumontite $\left(\mathrm{CaAl}_{2} \mathrm{Si}_{4} \mathrm{O}_{12} \cdot 4 \mathrm{H}_{2} \mathrm{O}\right)$, with which the equilibrium is achieved. It should be noted that the dissolution of primary aluminosilicates (in this case, anorthite) is accompanied by precipitation of clay minerals. One can see that in the system $\mathrm{SiO}_{2}-\mathrm{Al}_{2} \mathrm{O}_{3}-\mathrm{K}_{2} \mathrm{O}-\mathrm{CO}_{2}-\mathrm{H}_{2} \mathrm{O}$ (Fig. 3.c), the points are located in the stability fields of microcline, kaolinite, illite and montmorillonite. The concentrations of silicon compounds in thermal waters represent the decisive factor affecting the result of silicate hydrolysis. Lower $\mathrm{H}_{4} \mathrm{SiO}_{4}$ concentrations cause the formation of kaolinite and illite, while higher concentrations are liable for water saturation with respect to microcline. Investigations of the equilibria of formation waters with magnesium minerals (Fig. 3.d) showed that thermal waters are in equilibrium with respect to glaucophane $\left(\mathrm{Na}_{2}\left(\mathrm{Mg}, \mathrm{Fe}^{2+}\right)_{3} \mathrm{Al}_{2} \mathrm{Si}_{8} \mathrm{O}_{22}(\mathrm{OH})_{2}\right)$, kaolinite and $\mathrm{Mg}$-montmorillonite. 


\section{Conclusions}

Two types of thermal waters have been identified within the Bang thermal waters system. The waters from the first group $\left(62.1-97.1^{\circ} \mathrm{C}\right)$ with total mineralization $255-659 \mathrm{mg} / \mathrm{dm}^{3}$ and dominantly of $\mathrm{HCO}_{3}-\mathrm{Na}$ composition are supersaturated with respect to carbonate minerals (calcite, magnesite and dolomite) and saturated with respect to albite, microcline, laumontite and glaucophane. The second group is represented by thermal waters $\left(24.3-34.5^{\circ} \mathrm{C}\right.$ ) with mineralization $44-87 \mathrm{mg} / \mathrm{dm}^{3}$, of $\mathrm{HCO}_{3}-\mathrm{Cl}-\mathrm{Na}-\mathrm{Mg}$ composition. These are undersaturated with respect to carbonates and are located within the fields of stability of clay minerals: kaolinite, illite and $\mathrm{Na}-\mathrm{Ca}$-, and $\mathrm{Mg}$-montmorillonite. The data obtained are in good agreement with the results of the studies of the isotopic composition of hydrotherms $(\delta \mathrm{D}$, $\delta^{18} \mathrm{O}$ and ${ }^{3} \mathrm{H}$ ), according to which the time of circulation of the first-group waters must reach more than 60 years, while that for the second-group waters does not exceed 50 years.

\section{References}

1 D.A. Novikov, V.T. Doan, Proc. of the XII International Scientific Congress GEO-Sibir-2016, 94-98 (2016)

2 D.A. Novikov, V.T. Doan, T.K.V. Phan, N.A. Kharitonova Rus. Jour. of Pacif. Geol., 12, 63-79 (2018)

3 T.K.V. Phan, D.A.Novikov, V.T. Doan Proc. of the XIII International Scientific Congress GEO-Sibir-2017, 36-40 (2017)

4 V.T. Doan, T.K.V. Phan, F.V. Tran, D.A. Novikov, Proc. of the II All-Russia Conference participated by foreign scientists Geological Evolution of the Interaction of Water with Rocks, 234-237 (2015).

5 V.C. Nghiep, Hanoi, Vietnam Department of Geology and Mineral Resources, 300 (1998)

6 T.V. Nguyen, K.C. Nguyen, H. Long, D.M. Nguyen, T.T. Phan, Proc. of the international conference: Isotope and geochemical techniques applied to geothermal investigations, IAEA, 249-269 (1995)

7 C.V. Phan, $2^{\text {nd }}$ ed., Hanoi, Geological survey of Vietnam, 158 (1991)

8 H.H. Quy, Geothermics, 27, 109-115 (1998)

9 T. Tong-Dzuy, K. Vu, $2^{\text {nd }}$ ed., Hanoi, Vietnam National University Publisher, 554 (2011)

10 A.V. Tran, V.T. Doan, T.A. Tran, V.T. Dinh Proc. 42nd workshop on geothermal reservoir engineering Stanford University, 1-8 (2017)

11 A.S. Shchukarev, Proc. of the GGI, 64 (1934) 